\title{
REVIEW
}

\section{The role of membrane mucin MUC4 in breast cancer metastasis}

\author{
Courtney A Dreyer, Kacey VanderVorst, Savannah Free, Ashley Rowson-Hodel and Kermit L Carraway IIID \\ Department of Biochemistry and Molecular Medicine, and UC Davis Comprehensive Cancer Center, UC Davis School of Medicine, Sacramento,
} California, USA

Correspondence should be addressed to K L Carraway: klcarraway@ucdavis.edu

\begin{abstract}
A major barrier to the emergence of distant metastases is the survival of circulating tumor cells (CTCS) within the vasculature. Lethal stressors, including shear forces from blood flow, anoikis arising from cellular detachment, and exposure to natural killer cells, combine to subvert the ability of primary tumor cells to survive and ultimately seed distant lesions. Further attenuation of this rate-limiting process via therapeutic intervention offers a very attractive opportunity for improving cancer patient outcomes, in turn prompting the need for a deeper understanding of the molecular and cellular mechanisms underlying CTC viability. MUC4 is a very large and heavily glycosylated protein expressed at the apical surfaces of the epithelia of a variety of tissues, is involved in cellular growth signaling and adhesiveness, and contributes to the protection and lubrication of cellular linings. Analysis of patient-matched breast tumor specimens has demonstrated that MUC4 protein levels are upregulated in metastatic lesions relative to primary tumor among all breast tumor subtypes, pointing to a possible selective advantage for MUC4 overexpression in metastasis. Analysis of a genetically engineered mouse model of HER2-positive breast cancer has demonstrated that metastatic efficiency is markedly suppressed with Muc4 deletion and Muc4-knockout tumor cells are poorly associated with platelets and white blood cells known to support CTC viability. In this review, we discuss the diverse roles of MUC4 in tumor progression and metastasis and propose that intervening in MUC4 intercellular interactions with binding partners on blood-borne aggregating cells could potentially thwart breast cancer metastatic efficiency.
\end{abstract}

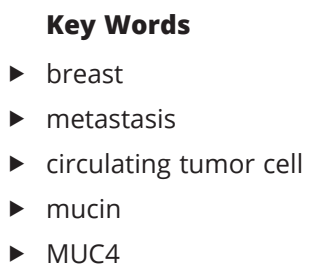

Endocrine-Related Cancer (2021) 29, R17-R32

\section{Introduction}

\section{Breast cancer metastasis}

Despite significant advances in the detection and treatment of breast tumors over the last few decades, metastatic disease remains the primary cause of breast cancer-related deaths (Weigelt et al. 2005). Metastasis is a multistep process involving primary tumor cell invasion into the stromal compartment, intravasation into the blood or lymphatic systems, extravasation from capillaries at secondary sites, and colonization and outgrowth of metastatic lesions (Talmadge \& Fidler 2010, Lambert et al. 2017). Metastasizing tumor cells exhibit unique characteristics including altered cellular adhesion, evasion of programmed cell death, induction of the epithelial-to-mesenchymal transition (EMT), and association with cells in circulation (Lambert et al. 2017). Important intermediaries of the distant metastatic cascade are circulating tumor cells (CTCs), which exit primary tumors as single cells or clusters and 
travel to distant sites to seed metastatic lesions (Lambert et al. 2017, Micalizzi et al. 2017). It has been estimated that only $\sim 0.01 \%$ of cells that enter circulation survive to seed metastatic lesions (Reymond et al. 2013), prompting questions concerning the mechanisms by which CTCs are able to shield themselves from the harsh conditions of transit.

While our understanding of the molecular underpinnings governing breast cancer metastasis has improved in recent years, our ability to successfully treat metastatic disease lags far behind. Novel methods and reliable markers to predict the probability of metastasis together with new approaches to therapeutically intervene could provide significant clinical benefit to the patients. Currently employed anti-metastatic therapeutic strategies closely align with those employed in the treatment of primary breast tumors and typically involve a combination of chemotherapeutics, targeted therapeutics, and immunotherapies (Scully et al. 2012, Ganesh \& Massagué 2021). A significant challenge to this approach is that metastatic lesions often accumulate genetic alterations that are molecularly distinct from primary tumors, rendering such therapeutic avenues ineffective (Fidler \& Kripke 1977, Ganesh \& Massagué 2021). Thus, increasing effort has been dedicated toward identifying new prognostic markers for metastasis and developing strategies to target processes that contribute to aggressive diseases, such as angiogenesis, cell motility, the metastatic microenvironment, metastatic dormancy, and CTCs (Fontebasso \& Dubinett 2015, Steeg 2016).

\section{Mucin proteins}

Mucins are large, heavily glycosylated cell-surface proteins that normally function to lubricate and protect epithelial and vascular surfaces. The human mucin family is comprised of at least 20 distinct members that fall into two categories: secreted and membrane-bound. Both classes are characterized by the presence of a highly $O$-glycosylated variable number of tandem repeat (VNTR) domain, which contributes to cell protection by forming a large, protruding, and negatively charged structure that helps physically shield the cell surface from external assaults (Van Klinken et al. 1995). However, each class is also distinguished by its own distinct domains and functions. The secreted mucins (including MUC2, MUC5AC, MUC5B, MUC6, MUC7, and MUC19) contain trypsin inhibitor-like (TIL), von Willebrand factor type D (vWD), and C-terminal cysteine-knot domains (Perez-Vilar \& Hill 1999) (Fig. 1A). Importantly, secreted mucins oligomerize through their cysteine-rich vWD and C-terminal cysteine-knot domains (Perez-Vilar \& Hill 1999), directly contributing to their ability to coat epithelial and vasculature structures and protect against outside infection and physical or chemical damage.

Membrane-bound mucins (including, MUC1, MUC3, MUC4, MUC12, MUC13, MUC15, MUC16, MUC17, and MUC20) also contain cysteine-rich regions similar to vWD domains and C-terminal cysteine-knot domains (Bansil \& Turner 2018) but are distinguished from secreted mucins by the presence of a single transmembrane domain that tethers them to the cell surface. All membrane-bound mucins contain a sea urchin sperm protein, enterokinase, and agrin (SEA) domain, with the exception of MUC4, which instead contains a nidogen domain and an adhesion-associated (AMOP) domain (Kufe 2009). Many of the transmembrane mucins also contain EGF-like domains important for interactions with other proteins (Fig. 1B). While transmembrane mucins also contribute to coating and protection of epithelial surfaces, they also appear to play additional roles in cell signaling (Carraway et al. 2003). Importantly, numerous studies have demonstrated that aberrant expression of membranebound mucins, most notably MUC1 and MUC4, confer aggressive characteristics to tumors by promoting cellular proliferation, motility, and survival (the contributions of MUC1 to malignancy are reviewed in Nath \& Mukherjee 2014, Chen et al. 2021). MUC4 has been widely implicated as a prominent contributor to breast cancer progression and metastasis (Workman et al. 2009a, Rowson-Hodel et al. 2018) and thus will be the focus of this review.

\section{Membrane mucin MUC4}

Mucin-4 (MUC4), a membrane-bound mucin, has been extensively studied in a diverse collection of normal tissues and solid tumors. Many of the foundational studies on MUC4 structure and expression patterns were performed in rat tissues over two decades ago, and key observations have been subsequently confirmed in human tissues following the cloning of the human gene (Moniaux et al. 1999). While MUC4 has been assigned diverse functions across many cell and tumor types, and function may be context-dependent in some cases, its central role as a mediator of metastasis is beginning to emerge. In this regard, MUC4 has been implicated as a regulator of several processes critical to metastasis, including cell adhesion (Komatsu et al. 1997), EMT and invasion (Moniaux et al. 2007), tumor cell docking (Senapati et al. 2012), therapeutic resistance (Price-Schiavi et al. 2002), and cell survival 


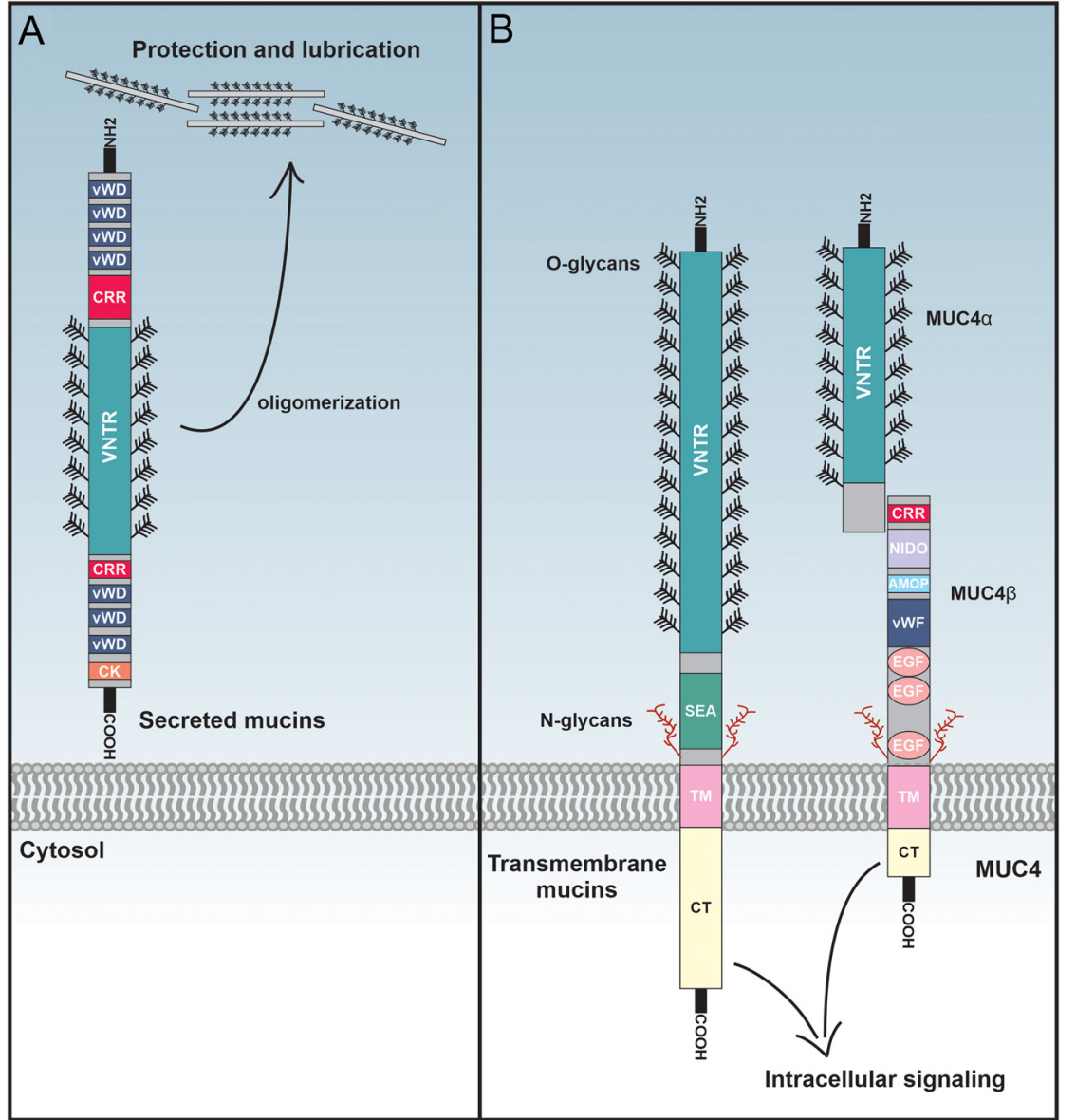

\section{Figure 1}

Structures of secreted and membrane-bound mucins. (A) Secreted mucins contain multiple VWD (von Willebrand factor D) domains, cysteine-rich regions (CRRs), as well as a single C-terminal cysteine-knot (CK) domain. The middle regions of the secreted mucins consist of a highly

O-glycosylated VNTR domain which contains cysteine-rich regions dispersed throughout. Secreted mucins oligomerize through their CRR and CK domains, forming large highly viscous aggregates that contribute to the lubrication and protection of epithelial surfaces. (B) Membranebound mucins are structurally similar to secreted mucins and contain vWD domains, CRRs, and O-glycosylated VNTR domains but are

distinguished by a single transmembrane domain that tethers them to the cell surface. Membranebound mucins also contain SEA domains as well as some $\mathrm{N}$-glycosylated regions. Notably, in MUC4 the SEA domain is replaced with NIDO and AMOP domains. MUC4 also contains three EGF-like domains and is proteolytically cleaved to produce noncovalently linked MUC4a and MUC4 $\beta$ subunits. While membrane-bound mucins are also critical to the protection and lubrication of epithelial surfaces, they can simultaneously play extensive roles in cellular signaling, often through their cytoplasmic tails.
(Carraway et al. 2001, Komatsu et al. 2001). Because of its recent identification as an important regulator of metastasis by aiding CTC survival in circulation by associating with blood cells (Rowson-Hodel et al. 2018), we will provide an overview of MUC4 characteristics, emphasizing its role as a mediator of CTC-blood cell associations, and discuss the implications of these observations in cancer progression and the development of anti-metastatic therapeutic strategies.

\section{Regulation of MUC4 expression}

MUC4 expression is regulated through a collection of diverse mechanisms throughout both transcription and translation. The MUC4 5' promoter region contains tissue-specific as well as positive and negative regulatory elements, underscoring the complex regulation of MUC4 by a plethora of signaling pathways (Price-Schiavi et al. 2000a, Perrais et al. 2001). For example, in rat mammary adenocarcinoma cells, the transcription factor PEA3 directly binds the Muc4 promoter and mediates Muc4 transcription via ERK and SAPK/JNK signaling (Perez et al. 2003). Others have reported that, in human epithelial cancer cells, MUC4 expression is spatiotemporally regulated by various transcription factors including HNF1/4, FOXA1/A2, GATA4/5/6, and CDX1/2 (Jonckheere et al. 2007). Similarly, CTNNB1 can directly bind to the promoter of MUC4 and alter transcript and protein levels in colorectal and pancreatic cancer cells in a Wnt-dependent manner (Pai et al. 2016a,b). Muc4 is also regulated by insulin and IGF1 in an ERK-dependent manner in rat mammary epithelial cells (Zhu et al. 2000), and the proinflammatory cytokine IL6 engages the GP130/STAT3 signaling pathway to stimulate the direct binding of phosphorylated-STAT3 to the MUC4 promoter in gastric cancer cells (Mejías-Luque et al. 2008).

Evidence suggests that MUC4 is also regulated epigenetically. In pancreatic cancer cells, the MUC4 5'UTR is methylated at $\mathrm{CpG}$ sites and inhibition of histone deacetylation alters MUC4 expression (Vincent et al. 2008). A similar study confirmed that methylation in the MUC4 promoter region regulates MUC4 expression and that the pattern of DNA methylation correlates with MUC4 
expression across a number of solid tumor types (Yamada et al. 2009).

MUC4 is transcriptionally induced in both normal and cancer tissues via hormonal and cellular transformation inputs, respectively. For example, in the rat uterine epithelium, Muc4 is transcriptionally regulated by ovarian hormones, such as estrogen and progesterone, where Muc4 expression patterns are important for proper blastocyst implantation (McNeer et al. 1998). On the other hand, MUC4 expression is elevated during pancreatic carcinogenesis by KRAS to engage MAPK, NFKB, and RALB signaling pathways (Vasseur et al. 2015) and by the FXR/ FAK/JUN signaling axis to promote pancreatic tumor progression and metastasis (Joshi et al. 2016).

It has also been observed that MUC4 expression is altered through the direct binding of multiple regulators to MUC4 mRNA in the 3' UTR. In mouse epithelial tissues, galectin-3 regulates Muc4 mRNA stability and expression through the intermediate hbRNP-L (Coppin et al. 2017). Moreover, Srivastava et al. (Srivastava et al. 2011) demonstrated that miRNA-150 directly binds to the 3' UTR of MUC4 mRNA to reduce MUC4 expression, resulting in decreased growth, clonogenicity, migration, and invasion but increased cell-cell adhesion of pancreatic cancer cells. Similarly, miR-219-1-3p negatively regulates MUC4 expression in pancreatic cancer cells by binding to the MUC4 3'UTR to decrease cell proliferation and downstream activation of AKT and ERK (Lahdaoui et al. 2015). In cervical cancer cells, miR-211 directly binds the MUC4 3' UTR to decrease MUC4 expression and cancer cell invasion, likely via reversal of EMT phenotypic properties (Xu et al. 2017).

TGFB has been identified as a major regulator of MUC4 at multiple levels. Price-Schiavi et al. (2000b) found that in the rat mammary epithelial cells, but not in tumor cells, MUC4 is post-transcriptionally upregulated by TGFB during pregnancy (Price-Schiavi et al. 1998), while in rat uterine luminal epithelial cells, regulation of MUC4 protein is controlled by TGFB expressed in the stroma and may be antagonized by estrogen (Idris \& Carraway 2000). Mechanistically, it has been observed that TGFB targets the MUC4 precursor protein for proteasomal degradation (Price-Schiavi et al. 1998, Lomako et al. 2009). In pancreatic tumor cells, retinoic acid alters MUC4 through direct regulation of TGFB expression (Choudhury et al. 2000). MUC4 was also found to be transcriptionally upregulated by TGFB in pancreatic cancer cells, and SMAD2/SMAD4 activation at the MUC4 promoter was negatively regulated by SMAD7 and SKI (Jonckheere et al. 2004). Similarly, SMAD2 regulates TGFB-induced Muc4 expression in mammary epithelial cells, whereas IFNG, through induction of STAT1 activation and upregulation of expression of the inhibitory SMAD7, inhibits the effect of TGFB on MUC4 expression (Soto et al. 2003). Together, these studies underscore the remarkably complex regulatory mechanisms governing MUC4 expression in both normal and cancer contexts.

\section{MUC4 structure and function}

\section{MUC4 structure}

MUC4 was identified as sialomucin complex (SMC) in a highly metastatic rat adenocarcinoma (Sherblom et al. $1980 a, b)$. Human MUC4 is located on chromosome 3q29 (Porchet et al. 1991, Gross et al. 1992), varies in length from 4468 to 8468 amino acid residues, and is highly similar in structure to rat MUC4 (Moniaux et al. 1999). The MUC4 precursor is synthesized in the endoplasmic reticulum where it is $\mathrm{N}$-glycosylated, folds and is then proteolytically cleaved to produce the two non-covalently associated subunits, MUC4 $\alpha$ and MUC4 $\beta$ (Sherblom \& Carraway 1980, Helm \& Carraway 1981, Sheng et al. 1990, Soto et al. 2006). MUC4 $\alpha$ contains the variable tandem repeat domain, which is subject to extensive $O$-glycosylation following cleavage of the precursor (Spielman et al. 1987, Nollet et al. 1998). O-glycans primarily contribute to the bulky and protruding structure of MUC4, which is important for the protection and lubrication functions of the complex. While the structure of the alpha subunit is quite similar between rat and human, human MUC4 contains a much more extensive variable tandem repeat domain, making the molecule significantly larger (Moniaux et al. 1999). The membrane-associated subunit MUC4 $\beta$ shares a $60-70 \%$ amino acid sequence identity between rat and human (Moniaux et al. 1999). MUC4 $\beta$ consists of a $\sim 120 \mathrm{kDa}$ extracellular region, a single hydrophobic transmembrane domain and a very short ( 20 residue) cytoplasmic tail. The extracellular region contains $\mathrm{N}$-glycosylation sites and two EGF-like domains (Sheng et al. 1992, Moniaux et al. 1999) that confer important roles to the MUC4 $\beta$ subunit in cell signaling (Wu et al. 1994, Carraway et al. 1999).

\section{MUC4 expression patterns}

MUC4 is expressed in numerous normal epithelial tissues during development and in adult (Rossi et al. 1996, Idris \& Carraway 1999, Price-Schiavi et al. 2000b, Zhang et al. 2005). In adult tissues, MUC4 is expressed in endothelial cells lining the vasculature (Zhang et al. 2005) and on 
the apical surfaces of epithelial cells, where it may serve as a marker of differentiation (Li et al. 2001). While early observations with a rat mammary adenocarcinoma model suggested that MUC4 may be overexpressed in tumors relative to normal tissues (Rossi et al. 1996), subsequent findings with patient samples indicate that MUC4 is aberrantly expressed across diverse solid tumor types and is often, but not always, correlated with worsened prognosis or advanced disease (Table 1). MUC4 expression is increased in the primary tumors of various breast tumor subtypes (Komatsu et al. 1999, Rakha et al. 2005, Mukhopadhyay et al. 2013, Shet et al. 2013, Mercogliano et al. 2017b), upper aerodigestive tract squamous cell carcinomas (Weed et al. 2001), ovarian tumors (Chauhan et al. 2006), pancreatic adenocarcinomas (Mimeault et al. 2010, Kaur et al. 2014), lung adenocarcinomas (Gao et al. 2014), the 'columnar type' of mucin-producing bile duct tumors (Shibahara et al. 2004b), glioblastomas (Li et al. 2014b), cervical tumors (Xu et al. 2017), and intrahepatic cholangiocarcinomas (Shibahara et al. 2004a) compared to normal tissues. In TCGA data sets, high MUC4 expression is correlated with poor patient survival in pancreatic cancer, bladder cancer, colon cancer, lung adenocarcinoma, lung squamous carcinoma, ovarian cancer, skin cancer, and stomach cancer. In these tumors, MUC4 expression is linked to genes involved in cell adhesion, cell-cell junctions, glycosylation, and cell signaling (Jonckheere \& Van Seuningen 2018).

In human breast tumors, MUC4 appears to undergo significant changes in expression throughout the tumor progression process. We previously assessed MUC4 protein abundance using tissue microarrays containing patientmatched normal breast tissue, primary breast tumor tissue, and lymph node metastases. In contrast to other studies, we observed decreased MUC4 expression in the primary tumors compared to matched normal tissues, followed by a recovery of MUC4 expression in lymph node metastases (Workman et al. 2009a). Low MUC4 expression in the primary tumor is consistent with the role of MUC4 as a marker of differentiation in epithelial cells (Li et al. 2001); as tumors develop, the cellular transition from a differentiated to a de-differentiated state decreases MUC4 expression (Gabbert et al. 1985). However, the increased expression of MUC4 in lymph node metastases suggests that MUC4 may confer an advantage to cells attempting to metastasize. These MUC4 expression trends were independent of ER/PR and HER2 status, pointing to a possible universal role of MUC4 in promoting breast cancer malignancy. Collectively, MUC4 expression in various cancer types and stages of the disease is highly diverse, suggesting that MUC4 function is likely dependent on the biological context.

\section{MUC4 as a mediator of tumor cell adhesion and cell-cell interactions}

A major function of MUC4 is the promotion of antiadhesiveness. The extensive modification of MUC4 $\alpha$ by $O$-linked glycans creates a bulky and rigid structure that contributes to steric hindrance and the approach of foreign pathogens, bodies, and molecules (Komatsu et al. 1997). Early studies in rat tissues suggest that overexpression of MUC4 disrupts both cell-cell and cell-substrate interactions, the degree to which is dependent on the number of repeats in the VNTR region, and the extent of O-glycosylation of the rat MUC4 $\alpha$ subunit (Komatsu et al. 1997). $N$-glycosylation of the MUC4 $\beta$ extracellular domain can also contribute to the steric hindrance properties of MUC4, enabling the protein to mask the cell surface and prevent the binding of molecules to their substrates (Komatsu et al. 1997). In normal polarized human mammary epithelial cells, overexpression relocalizes MUC4 from the apical surface to the lateral surfaces of epithelial cells, resulting in disruption of adherens junctions and impairing cell-cell attachments (Pino et al. 2006). Additionally, MUC4 overexpression in pancreatic tumor cells disrupts tumor cell-extracellular matrix (ECM) interactions by inhibiting integrin-mediated cell adhesion (Chaturvedi et al. 2007) and inhibits cell adhesion and aggregation by preventing interactions between MUC4expressing tumor cells (Singh et al. 2004). Importantly, loss of MUC4 in melanoma cells results in a rapid reversal from a non-adherent to an adherent state (Komatsu et al. 1997), a process critical to metastasis. In rat mammary adenocarcinoma, MUC4 expression on the cell surface aids in tumor cell evasion of immune killing by masking antigens for immune cell recognition through steric disruption of interactions between tumor cells and cytotoxic immune cells (Sherblom \& Moody 1986, Komatsu et al. 1999). While MUC4 is an important mediator of anti-adhesiveness, the ability of MUC4 to directly engage molecules on the surface of other cells appears to promote adhesion in some biological contexts. In human pancreatic cancer cells, surface MUC4 interacts with galectin-3 on endothelial cells to support the attachment and docking of CTCs to the endothelium, a process essential for extravasation and seeding of metastatic colonies (Senapati et al. 2012). Together, these studies demonstrate that MUC4 mediates a diverse array of cell-cell adhesion and cellular interactions that promote metastasis. 
Table 1 Muc4 expression in primary tumors and metastatic lesions.

\begin{tabular}{|c|c|c|c|c|c|}
\hline Cancer type & $\begin{array}{l}\text { Muc4 expression patterns } \\
\text { (primary tumor) }\end{array}$ & $\begin{array}{l}\text { Muc4 expression } \\
\text { patterns (metastases) }\end{array}$ & $\begin{array}{l}\text { Correlation with } \\
\text { prognostic factor or } \\
\text { disease stage }\end{array}$ & $\begin{array}{l}\text { Method of } \\
\text { detection }\end{array}$ & Reference \\
\hline \multirow[t]{6}{*}{ Breast cancer } & $\begin{array}{l}\text { Expressed in } 95 \% \text { of } \\
\text { primary breast tumors }\end{array}$ & NR & $\begin{array}{l}\text { Muc4 expression } \\
\text { correlates with } \\
\text { tumor grade }\end{array}$ & $\mathrm{IHC}$ & $\begin{array}{l}\text { (Rakha et al. } \\
\text { 2005) }\end{array}$ \\
\hline & $\begin{array}{l}\text { Overexpressed in } \\
\text { primary invasive } \\
\text { triple-negative tumors } \\
\text { compared to normal }\end{array}$ & NR & NR & $\mathrm{IHC}$ & $\begin{array}{l}\text { (Mukhopadhyay } \\
\text { et al. 2013) }\end{array}$ \\
\hline & $\begin{array}{l}\text { Expressed in the majority } \\
\text { of secretory carcinomas } \\
\text { of the breast }\end{array}$ & $\begin{array}{l}\text { No increased } \\
\text { expression in } \\
\text { metastatic lesions }\end{array}$ & NR & $\mathrm{IHC}$ & (Shet et al. 2013) \\
\hline & $\begin{array}{l}\text { Decreased expression in } \\
\text { primary tumor } \\
\text { compared to patient- } \\
\text { matched normal }\end{array}$ & $\begin{array}{l}\text { Increased expression } \\
\text { in patient-matched } \\
\text { lymphnode } \\
\text { metastases }\end{array}$ & NR & WB/IHC & $\begin{array}{l}\text { (Workman et al. } \\
2009 a, b)\end{array}$ \\
\hline & $\begin{array}{l}\text { Expressed in majority of } \\
\text { patient breast cancer } \\
\text { samples }\end{array}$ & NR & $\begin{array}{l}\text { High frequency of } \\
\text { Muc4 expression in } \\
\text { malignant cells in } \\
\text { body fluids }\end{array}$ & ICC & $\begin{array}{l}\text { (Komatsu et al. } \\
\text { 1999) }\end{array}$ \\
\hline & $\begin{array}{l}\text { Highly expressed in } \\
\text { invasive micropapillary } \\
\text { carcinoma of the breast }\end{array}$ & NR & $\begin{array}{l}\text { Muc4 expression } \\
\text { correlates with } \\
\text { shorter death free } \\
\text { survival and poor } \\
\text { response to standard } \\
\text { of care }\end{array}$ & $\mathrm{IHC}$ & $\begin{array}{l}\text { (Mercogliano } \\
\text { et al. 2017a,b) }\end{array}$ \\
\hline $\begin{array}{l}\text { Aerodigestive tract } \\
\text { squamous } \\
\text { cell cancer }\end{array}$ & $\begin{array}{l}\text { Expressed in primary } \\
\text { tumors }\end{array}$ & $\begin{array}{l}\text { Expression persists in } \\
\text { metastatic lesions }\end{array}$ & $\begin{array}{l}\text { No correlation with } \\
\text { patient prognosis }\end{array}$ & ICC/WB & $\begin{array}{l}\text { (Weed et al. } \\
\text { 2001) }\end{array}$ \\
\hline Ovarian cancer & $\begin{array}{l}\text { Overexpressed in } \\
\text { primary tumor } \\
\text { compared to normal } \\
\text { tissue }\end{array}$ & NR & $\begin{array}{l}\text { No correlation with } \\
\text { patient survival }\end{array}$ & $\mathrm{IHC}$ & $\begin{array}{l}\text { (Chauhan } \\
\text { et al. 2006) }\end{array}$ \\
\hline \multirow[t]{2}{*}{ Pancreatic cancer } & $\begin{array}{l}\text { Overexpressed in } \\
\text { primary tumor } \\
\text { compared to normal } \\
\text { tissue }\end{array}$ & NR & NR & $\mathrm{IHC}$ & $\begin{array}{l}\text { (Mimeault et al. } \\
\text { 2010) }\end{array}$ \\
\hline & $\begin{array}{l}\text { Expressed in primary } \\
\text { tumors }\end{array}$ & NR & $\begin{array}{l}\text { Muc4 expression } \\
\text { correlates with } \\
\text { disease progression }\end{array}$ & $\mathrm{IHC}$ & (Kaur et al. 2014) \\
\hline Lung cancer & $\begin{array}{l}\text { Highly expressed in } \\
\text { primary tumor }\end{array}$ & $\begin{array}{l}\text { Decreased expression } \\
\text { in lymph node } \\
\text { metastases }\end{array}$ & $\begin{array}{l}\text { Correlates with risk of } \\
\text { lymph node } \\
\text { metastasis }\end{array}$ & WB & (Gao et al. 2014) \\
\hline Glioblastoma & $\begin{array}{l}\text { Upregulated in tumor } \\
\text { compared to normal } \\
\text { tissue }\end{array}$ & NR & NR & WB/IHC & (Li et al. 2014a,b) \\
\hline Cervical cancer & $\begin{array}{l}\text { Overexpressed in } \\
\text { primary tumor } \\
\text { compared to normal } \\
\text { tissue }\end{array}$ & NR & $\begin{array}{l}\text { Strongly associated } \\
\text { with lymph node } \\
\text { metastases }\end{array}$ & $\begin{array}{l}\text { IHC/gene } \\
\text { microarray }\end{array}$ & (Xu et al. 2017) \\
\hline \multirow[t]{2}{*}{ Cholangiocarcinoma } & $\begin{array}{l}\text { Expressed in 'columnar } \\
\text { type' primary tumors }\end{array}$ & NR & $\begin{array}{l}\text { No correlation with } \\
\text { patient prognosis }\end{array}$ & $\mathrm{IHC}$ & $\begin{array}{l}\text { (Shibahara et al. } \\
\text { 2004b) }\end{array}$ \\
\hline & $\begin{array}{l}\text { Overexpressed in } \\
\text { intrahepatic type } \\
\text { compared to normal } \\
\text { tissue }\end{array}$ & NR & $\begin{array}{l}\text { Correlates with patient } \\
\text { prognosis }\end{array}$ & $\mathrm{IHC}$ & $\begin{array}{l}\text { (Shibahara et al. } \\
\text { 2004a) }\end{array}$ \\
\hline
\end{tabular}

ICC, immunocytochemistry; IHC, immunohistochemistry; NR, not reported; WB, western blotting.

(c) 2021 Society for Endocrinology Published by Bioscientifica Ltd. Printed in Great Britain 


\section{MUC4 contribution to cellular survival mechanisms}

MUC4 also contributes to anti-apoptotic signals in cancer cells to promote tumor growth and metastasis through its membrane-associated beta subunit. Overexpression of rat MUC4 in human melanoma cells promotes xenografted tumor growth through suppression of cell death rather than alteration of cellular proliferation by directly regulating cell survival signals (Carraway et al. 2001, Komatsu et al. 2001). In human breast cancer cells, MUC4 suppresses apoptosis through mechanisms both dependent and independent of the HER2 (ERBB2) receptor tyrosine kinase, in some contexts signaling through the PI3K/AKT pathway (Workman et al. 2009b). Additionally, increased MUC4 expression in melanoma cells decreases the expression of the cell-cycle inhibitor CDKN1B, inactivates the proapoptotic protein $\mathrm{BAD}$, and increases expression of the prosurvival protein BCLXL (Jepson et al. 2002, Workman et al. 2009b). Similar effects were observed in pancreatic tumor cells, where upregulation of MUC4 expression leads to increased cell proliferation and decreased cell death (Chaturvedi et al. 2007). Importantly, regulation of cell survival signals by MUC4 was observed in response to a variety of insults, including chemotherapeutic agents, lack of serum factors, and loss of adhesion (Workman et al. 2009b). In contrast, loss of MUC4 reduces ERBB2/HER2mediated signaling, induces FOXO1 transcription, and promotes caspase 3-mediated apoptosis in ovarian cancer cells (Bae et al. 2017). These combined observations support a role for MUC4 as a potent regulator of programmed cell death through diverse signals, a feature critical for successful metastatic dissemination and survival of CTCs in circulation.

\section{MUC4 contribution to therapeutic resistance}

Consistent with the anti-adhesive and cell survival properties ascribed to the MUC4 $\alpha$ and MUC4 $\beta$ subunits, MUC4 has also been implicated in mediating therapeutic resistance through steric hindrance and regulation of programmed cell death. Human ER+/HER+ breast cancer cells orthotopically transplanted into mice exhibit upregulated MUC4 expression after therapeutic intervention with tamoxifen, an ER-targeted therapy (Chen et al. 2012). Additionally, ERBB2/HER2 receptor tyrosine kinase expression and signaling are elevated post tamoxifen treatment, implying that MUC4 contributes to a phenotypic switch to ERBB2/HER2 dependence and renders ER-targeted therapeutics ineffective (Chen et al. 2012). Moreover, it appears that MUC4 directly blocks therapeutic efficacy through steric hindrance at the cell surface. Indeed, cell surface MUC4 in melanoma and breast cancer cells reduced binding of anti-HER2 antibodies through steric hindrance and the formation of MUC4-ERBB2/HER2 complexes, which prevents binding of the anti-HER2 antibody Herceptin to its target (PriceSchiavi et al. 2002). Consistent with these findings, MUC4 expression is significantly higher in the Herceptin-resistant breast cancer cell line JIMT-1 compared with Herceptinsensitive lines and correlates with less binding of Herceptin to HER2. Importantly, RNAi-mediated MUC4 suppression restores Herceptin binding (Nagy et al. 2005). The mechanisms by which MUC4 is upregulated to promote therapeutic resistance appear varied and highly contextdependent. Studies by Mercogliano et al. suggest that the upregulation of MUC4 and reduction of Herceptin binding and efficacy in HER2-positive breast cancers may be TNFAdependent (Mercogliano et al. 2017a). However, others have observed that breast and gastric cancer cells treated with Herceptin exhibit STAT3-dependent upregulation of MUC1 and MUC4, blocking Herceptin binding to HER2 to mediate therapy resistance (Li et al. 2014a).

The ability of MUC4 to regulate programmed cell death and cell survival provides yet another mechanism by which MUC4 mediates therapeutic resistance. In pancreatic tumor cells, MUC4 promotes both cell survival and resistance to apoptosis, rendering the tumor cells resistant to gemcitabine, a commonly employed chemotherapeutic, and shRNA-mediated MUC4 knockdown re-sensitizes tumor cells to the cytotoxicity (Mimeault et al. 2010). Mechanistically, overexpression of MUC4 in pancreatic tumor cells appears to engage an ERBB2/HER2-ERK signaling axis that results in the inactivation of BAD and resistance to apoptosis (Bafna et al. 2009). Together, these studies demonstrate that MUC4 engages multiple signaling pathways and mechanisms to mediate therapeutic resistance to both HER2-targeted and other therapeutics, enabling tumor cells to adapt and progress to malignancy.

\section{MUC4 signaling}

\section{Signaling through ERBB2/HER2}

Over two decades of studies point to a role for MUC4 as an intramembrane binding partner for ERBB2 (human form referred to as HER2). MUC4 $\beta$ was shown to directly interact with the extracellular domain of ERBB2/HER2 via one of its EGF-like domains (Carraway et al. 1999). Subsequent studies demonstrated that MUC4 induces 
ERBB2/HER2 phosphorylation on tyrosine residues 1139 and 1248 (Jepson et al. 2002, Ramsauer et al. 2003, 2006) and that ectopic MUC4 potentiates neuregulin-1-mediated ERBB2/HER2 signaling (Carraway et al. 1999). Investigation of the complex revealed that MUC4 alters the subcellular localization of ERBB2/HER2 in diverse cellular contexts. For example, in the developing rat mammary gland, MUC4 and ERBB2/HER2 are localized to the apical and basolateral membranes, respectively, and expression of ERBB2/HER2 and MUC4 is controlled through distinct regulatory mechanisms. However, during late pregnancy and lactation, MUC4 and ERBB2/HER2 form a complex that is localized to apical cell surfaces in the rat mammary gland epithelia. Similarly, MUC4 promotes the re-localization of phosphorylated ERBB2/HER2 from the basolateral surface to the apical surface of epithelial cells without altering cell polarity (Ramsauer et al. 2003). The apical localization of ERBB2/HER2 may serve to segregate it from its dimerization partner ERBB3/HER3 and to activate ligands to alter signaling and downstream outcomes. Despite segregation, ERBB2/HER2 signals through p38-MAPK and AKT, providing evidence that MUC4 independently stimulates ERBB2/HER2 signaling (Ramsauer et al. 2006).

In melanoma and breast cancer cells, MUC4 expression promotes PI3K recruitment to ERBB3/HER3 at the plasma membrane and potentiates ERBB2/HER2-ERBB3/HER3-PI3K signaling (Funes et al. 2006). However, MUC4 expression significantly increases Neuregulin-1 ligand binding to ERBB2/HER2 and ERBB3/HER3 in these cells but does not impact receptor protein levels (Funes et al. 2006). These findings suggest that MUC4 potentiates ERBB2/HER2 signaling by trafficking both receptors to the plasma membrane from intracellular compartments and by suppressing receptor internalization (Funes et al. 2006). In ovarian cancer cells, MUC4 increases both ERBB2/HER2 expression and signaling through FAK-AKT-ERK (Ponnusamy et al. 2008).

In pancreatic and ovarian cancer cells, MUC4 appears to stabilize ERBB2/HER2 and drive signaling through the FAK, MAPK, and JNK pathways, contributing to cancer cell proliferation, migration, and invasion (Chaturvedi et al. 2008, Ponnusamy et al. 2011, Jonckheere et al. 2012). Consistently, stabilization of ERBB2/HER2 by MUC4 in pancreatic cancer cells results in PI3K-dependent activation of AKT, increased signaling through NFKB, and elevation of the expression of lipocalin 2, a multifunctional glycoprotein that may serve as a potential biomarker during tumor progression (Kaur et al. 2014). Additionally, MUC4 increases ERBB2/HER2-FAK-SRC signaling, which results in the lysosome-dependent degradation of
E-cadherin and CTNNB1-mediated Wnt-signaling, driving pancreatic cancer cell proliferation and metastasis, as well as angiogenesis (Zhi et al. 2014).

\section{Signaling through other axes}

MUC4 can also signal through other EGFR family proteins, including EGFR and ERBB3/HER3. In triplenegative breast cancer, MUC4 increases expression of EGFR and ERBB3/HER3, activating ERK1/2, PKC, and FAK to drive cell proliferation, motility, and invasiveness in vitro, as well as increasing tumor growth and metastasis in vivo (Mukhopadhyay et al. 2013). In pancreatic cancer, MUC4 interacts with ERBB3/HER3 in the absence of ERBB2/HER2 to mediate signaling through PI3K/ERK/MYC to increase cell proliferation and signaling through FAK/SRC to mediate cell motility (Lakshmanan et al. 2015). In glioblastoma, MUC4 mediates higher cell proliferation and invasiveness through the regulation of EGFR expression (Li et al. $2014 b$ ). In pancreatic cancer cells, overexpression of MUC4/Y, a splice variant that lacks much of the alpha subunit, enhances both angiogenic and metastatic properties of cells in vitro and in vivo through activation of NOTCH3 signaling and correlates with a decreased overall survival in vivo (Tang et al. 2016).

MUC4 is a mediator of cell motility events critical to metastasis in a variety of solid tumor types (Chaturvedi et al. 2007, Moniaux et al. 2007, Ponnusamy et al. 2008, 2010). Mechanistically, MUC4-mediated motility is driven by reorganization of the actin cytoskeleton, including the formation of microspikes, lamellipodia, and filopodialike structures (Chaturvedi et al. 2007, Ponnusamy et al. 2008). Further support for the role of MUC4 in promoting metastatic behavior comes from studies demonstrating that MUC4 may be a critical regulator of EMT in multiple tumor types. In ovarian cancer cells, MUC4 overexpression was observed to drive a phenotypic shift from an epithelial-like cellular morphology to a mesenchymal-like cellular morphology, decreased expression of epithelial markers such as E-cadherin and cytokeratin-18, and increased expression of mesenchymal markers including $\mathrm{N}$-cadherin and vimentin (Ponnusamy et al. 2008). Further investigation demonstrated that these expression changes were mediated by the EMT-inducing transcription factors TWIST1, TWIST2, and SNAIL (Ponnusamy et al. 2010). MUC4-mediated induction of EMT was also observed in pancreatic cancer and lung adenocarcinoma cells via an FGFR1-CTNNB1-dependent mechanism (Rachagani et al. 2012, Gao et al. 2014). 


\section{MUC4 involvement in circulating tumor cell survival}

\section{Circulating tumor cells}

CTCs are a heterogeneous population of cells that leave the primary tumor and seed metastases through the acquisition of characteristics that support their exit from primary lesions, entry into the vasculature, survival in circulation, and ability to colonize and proliferate at distant tissues. CTCs can access the vasculature through either passive shedding from the primary tumor or through local invasion and intravasation. Tumors cells are able to invade from the primary tumor through multiple modes of migration including single-cell invasion, where single cells undergo EMT and acquire a mesenchymal and invasive phenotype (Pantel \& Speicher 2016), and collective invasion, where cells enter circulation collectively and transit the vasculature as clusters (VanderVorst et al. 2019). While CTCs largely exist as single cells, Aceto et al. reported that in mouse models of breast cancer, CTCs form clusters of 2-50 cells in circulation. While rare compared to single CTCs, these clusters are 20- to 50-fold more metastatic than single CTCs (Aceto et al. 2014). Indeed, the presence of CTC clusters in the bloodstream of breast cancer patients is correlated with poor clinical outcomes (Wang et al. 2017).

CTCs and CTC clusters must also survive the harsh environment of circulation by withstanding shear forces, evading immune attack, and suppressing anoikis. Through acquired mesenchymal and stem-like features, often driven by stemness-associated gene upregulation via transcription factor binding site hypomethylation, breast CTC clusters achieve enhanced anchorage-independent growth and metastasize more effectively than single CTCs (Gkountela et al. 2019). Furthermore, studies in lung and breast cancer suggest that association with stromal cells (e.g. cancer-associated fibroblasts (CAFs), tumor-associated macrophages (TAMs), and endothelial cells) from primary tumors increases CTC viability both in the bloodstream and at metastatic sites by conferring shear stress resistance (Duda et al. 2010) and by stimulating angiogenesis and EMT (Matsumura et al. 2019), respectively.

While the characterization of CTCs is crucial to our understanding of metastasis, their very low abundance in the bloodstream and heterogeneity make both identification and isolation difficult. Thus, much effort has been put into improving the detection and enrichment of CTCs in circulation through selection techniques based on biological and physical properties (reviewed in Zhu et al. 2018). Emerging advancements in CTC technologies and analysis will further increase our understanding of their involvement in metastatic disease and hopefully augment their potential as biomarkers of disease progression and therapeutic response.

\section{MUC4 involvement in CTC viability}

Initial observations that MUC4 protein is more abundant in metastatic lesions compared to patient-matched primary tumors led to speculation that MUC4 may aid in successful metastatic dissemination (Workman et al. 2009a). Our studies employing MUC4-deficient mice crossed into the NDL (Neu DeLetion mutant) murine model of ERBB2/HER2-induced mammary tumorigenesis revealed that MUC4 ablation significantly reduces the number of metastatic lesions in the lungs (RowsonHodel et al. 2018). Importantly, neither any differences in primary tumor growth rates or tumor burden are observed between MUC4 ${ }^{\mathrm{WT}} / \mathrm{NDL}$ and MUC4 ${ }^{\mathrm{KO}} / \mathrm{NDL}$ animals nor there is any effect of MUC4 knockout on NDL tumor cell migration in vitro. A tail-vein mouse model of metastasis using MUC4 ${ }^{\mathrm{WT}} / \mathrm{NDL}$ and MUC4 ${ }^{\mathrm{KO}} / \mathrm{NDL}$ tumor-derived cells recapitulated MUC4 impact on lung metastatic colonization, demonstrating that differences could not be attributed to unequal access to the vasculature. Combined with the observation that MUC4 ablated tumor-derived cells are less viable in suspension in vitro, these findings support a role for MUC4 in promoting cell survival in circulation (Rowson-Hodel et al. 2018).

CTCs are known to form aggregates in circulation with other tumor cells, immune cells, and platelets (Gay \& Felding-Habermann 2011). Loss of MUC4 in NDL tumorderived CTCs exhibited significantly impaired abilities to interact with platelets compared to their MUC4-expressing counterparts both in vitro and in vivo, suggesting that MUC4 may aid in the metastatic process through this mechanism. In this model, MUC4-expressing cells promote cell-cell aggregates with platelets and immune cells in circulation, aiding CTC survival in the vasculature and more efficiently seeding metastatic lesions. On the other hand, MUC4-negative cells are less able to form CTC-blood cell aggregates, thus rendering them unable to survive non-adherent conditions and impairing their successful colonization of metastatic lesions (Fig. 2).

CTCs have a short survival time in circulation, necessitating the acquisition of survival advantages during transit. Association of tumor cells with blood cells is a longrecognized means by which CTCs are bolstered against harsh bloodstream conditions (Gasic et al. 1968). Since 
Gasic and colleagues first observed metastatic suppression via thrombocytopenia more than 50 years ago (Gasic et al. 1968), researchers have identified essential roles for platelets in CTC immune evasion, cell survival, and invasiveness (Nieswandt et al. 1999). While aggregation of CTCs with platelets is variable and largely dependent on the tumor type, this process is generally thought to enhance metastatic capabilities. Mechanistically, enhanced metastatic potential is mediated by diverse drivers including the induction of tumor cell proliferation, the facilitation of tumor cell extravasation, and the enhancement of tumor cell interactions with the extracellular matrix (Tsuruo et al. 1986). Importantly, CTC-platelet aggregation occurs within minutes of entry into the bloodstream and plays a critical role in evasion of immune surveillance by 'cloaking' CTCs from natural killer (NK) cells and in promoting survival in the face of harsh environmental factors (Nieswandt et al. 1999, Palumbo et al. 2005). CTCs have also been observed to interact with circulating immune cells such as neutrophils, which mediate cell-cycle progression and increased CTC adhesion at secondary sites to facilitate metastatic seeding (Huh et al. 2010).

Given the contribution of CTC-platelet interactions to metastatic dissemination, significant effort has been put into identifying mechanisms to intervene in this association to clinically address metastasis. Currently, platelet inhibitors (Lou et al. 2015), platelet-mimicking drug delivery nanovehicles (Hu et al. 2015), and genetic engineering of platelets (Li et al. 2016) are being investigated to determine if disruption of CTC-platelet interactions might provide significant clinical benefit to cancer patients. Findings by Rowson-Hodel et al. that MUC4 is an essential component of platelet-CTC interactions suggest that MUC4 may be a viable therapeutic target for eliminating CTCs in the vasculature (Rowson-Hodel et al. 2018). Further evidence supporting the targeting of mucins during CTC transit in the vasculature comes from observations that sialic acid-containing glycans mediate tumor cell-platelet aggregation (Bastida et al. 1987), and a portion of mucin glycan side chains terminate in negatively charged sialic acids (Linden et al. 2008). These observations implicate transmembrane mucins, such as MUC4, as important mediators of CTC-blood cell interactions critical to successful metastatic dissemination and highlight the need for a better understanding of the molecular mechanisms underlying CTC-blood cell interactions to identify druggable targets for clinically addressing metastasis.

\section{Potential therapeutic strategies}

Because CTC viability is a remarkably stringent barrier to metastatic efficiency, squeezing that bottleneck tighter by suppressing MUC4-mediated interactions of CTCs with other blood-borne cells offers a tremendous opportunity to intervene in metastatic efficiency. A MUC4/CTC-based

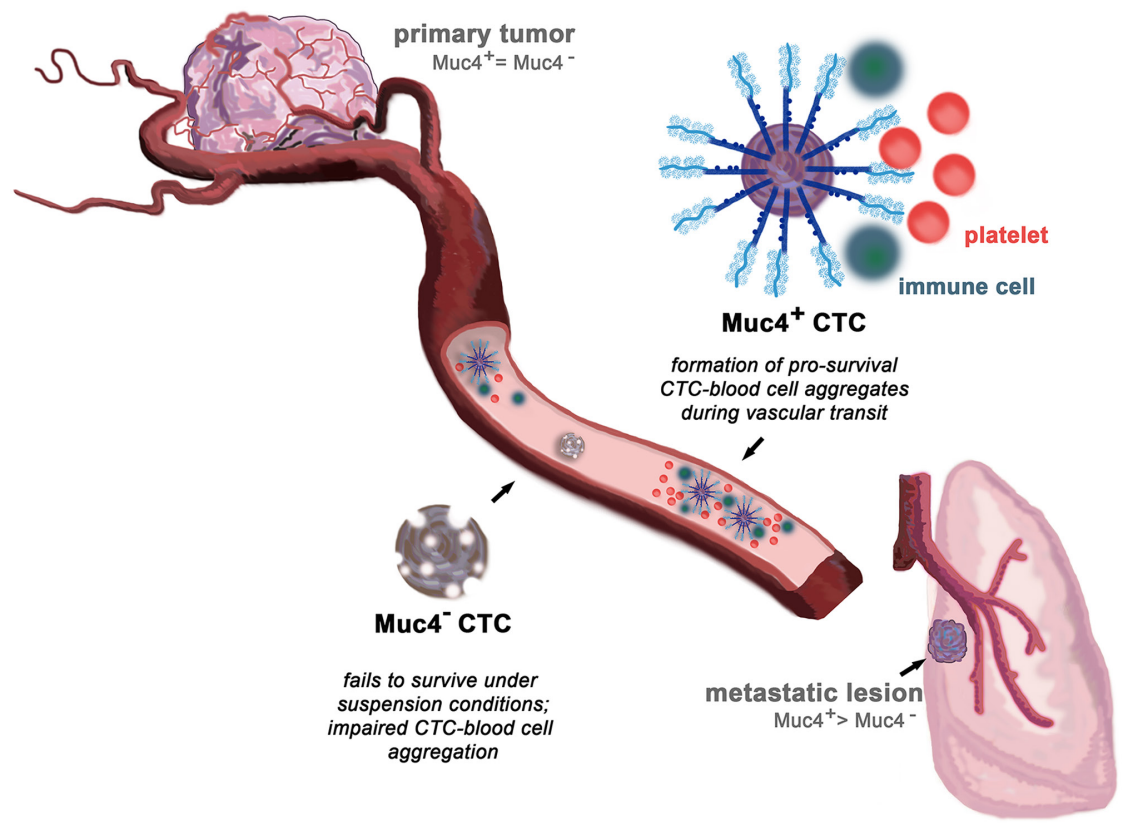

Figure 2

Muc4 mediates CTC survival in circulation. Muc4-positive CTCs form pro-survival cell aggregates with blood-borne cells during vascular transit, enabling them to more efficiently seed metastatic lesions at distant organs. On the other hand, Muc4-negative CTCs fail to survive the harsh conditions of transit, succumbing to shear forces and undergoing anoikis. These cells are unable to form CTC-blood cell aggregates, impairing their ability to successfully colonize metastatic lesions (Rowson-Hodel et al. 2018). (c) 2021 Society for Endocrinology Published by Bioscientifica Ltd. Printed in Great Britain 
strategy would necessarily involve the systemic delivery of an anti-MUC4 agent to CTCs via the vasculature, and such an agent would likely be a component of maintenance therapy following primary treatment. However, the development of such a strategy will likely be hampered by high MUC4 expression in intestinal epithelial and vascular endothelial cells, each of which could serve as a competing sink for small molecule or biologics in delivery to tumors. Targeting transcriptional regulators of MUC4 expression is another possible path to therapeutic intervention. However, because such transcriptional regulators control broad expression programs in multiple tissue types, the advantage of tumor-specific MUC4 targeting is lost with this approach. Likewise, strategies to provoke cytokine-induced MUC4 degradation in CTCs also suffer from specificity issues, and strategies to deliver MUC4targeting knockdown or knockout agents via CTC-directed nanoparticles could be rendered ineffective by the reported ability of highly expressed MUC4 to interfere with the binding of large molecules and complexes to the cell surface (Komatsu et al. 1997, Price-Schiavi et al. 2002, Nagy et al. 2005). Thus, the most promising avenue for therapeutic intervention will likely involve the identification of the MUC4 binding components on blood-borne cells and the inhibition of those contacts to reduce CTC viability. In this regard, it is reasonable to suspect that MUC4 is simply a major presenter of tumor cell-enriched glycan motifs recognized by lectins and other carbohydratebinding proteins and that glycomic studies with CTCs could provide key insight into the nature of intravascular cell-cell interactions as well as inform the development of novel therapeutic approaches.

\section{Conclusions and future directions}

Based on its structure, expression patterns, and function, MUC4 is beginning to emerge as an attractive target for therapeutic intervention into metastatic cancer. A large and growing body of evidence points to roles for aberrant MUC4 expression in the progression of a variety of solid tumor types. At the same time, studies of the full knockout mouse demonstrate that MUC4 is not essential for development, viability, or fertility and that its ablation has minimal impact on adult tissue morphology and function, strongly suggesting that systemic approaches for targeting MUC4 could elicit minimal side effects. While MUC4 appears to harbor an array of functions that might benefit the progression of a growing tumor, its role in promoting CTC viability is particularly intriguing. For example, observations from the study of patient-matched breast cancer patient samples and a genetically engineered mouse model of breast cancer indicate that the re-expression of MUC4 during the transition from primary to metastatic tumor drives metastatic efficiency at least in part by promoting CTC viability in circulation. This conclusion then raises the possibility that the process of MUC4-mediated CTC survival may be targeted for the benefit of breast cancer patients whose tumors are at risk of distant metastasis.

While the role of MUC4 in CTC-mediated breast cancer metastasis is most well-characterized, it is likely that MUC4 plays roles in CTC stabilization of other carcinomas as well. The immediate availability of a MUC4 knockout mouse with few discernable developmental phenotypes will facilitate analogous studies with genetically engineered mouse models of other tumor types. As with breast cancer, such studies will be most impactful when coupled with MUC4 expression surveys of patient-matched primary and metastatic lesions. For these studies, it will be essential to employ immunohistochemical or other protein-based methods as it has been demonstrated that MUC4 protein stability is highly dependent on factors produced by the microenvironment (Price-Schiavi et al. 1998, 2000b, Lomako et al. 2009). Finally, a particularly interesting question concerns the role of MUC4 in CTC self-association, an issue not previously addressed in the MUC4 knockout study (Rowson-Hodel et al. 2018). Because clusters are 1-2 orders of magnitude more potent in seeding metastases than single CTCs, the identification of homotypic cell-cell contacts is an issue of immediate interest.

\section{Declaration of interest}

The authors declare that there is no conflict of interest that could be perceived as prejudicing the impartiality of this review.

\section{Funding}

This work was supported by the NIH grants CA230742 and CA250211 (K L C), and NIH fellowship CA246900 (C A D).

\section{References}

Aceto N, Bardia A, Miyamoto DT, Donaldson MC, Wittner BS, Spencer JA, Yu M, Pely A, Engstrom A, Zhu H, et al. 2014 Circulating tumor cell clusters are oligoclonal precursors of breast cancer metastasis. Cell 158 1110-1122. (https://doi.org/10.1016/j.cell.2014.07.013)

Bae JS, Lee J, Park Y, Park K, Kim JR, Cho DH, Jang KY \& Park SH 2017 Attenuation of MUC4 potentiates the anticancer activity of auranofin via regulation of the Her2/Akt/FOXO3 pathway in ovarian cancer cells. Oncology Reports 38 2417-2425. (https://doi.org/10.3892/or.2017.5853) (c) 2021 Society for Endocrinology Published by Bioscientifica Ltd. Printed in Great Britain 
Bafna S, Kaur S, Momi N \& Batra SK 2009 Pancreatic cancer cells resistance to gemcitabine: the role of MUC4 mucin. British Journal of Cancer 101 1155-1161. (https://doi.org/10.1038/sj.bjc.6605285)

Bansil R \& Turner BS 2018 The biology of mucus: composition, synthesis and organization. Advanced Drug Delivery Reviews 124 3-15. (https:// doi.org/10.1016/j.addr.2017.09.023)

Bastida E, Almirall L, Jamieson GA \& Ordinas A 1987 Cell surface sialylation of two human tumor cell lines and its correlation with their platelet-activating activity. Cancer Research 47 1767-1770.

Carraway 3rd KL, Rossi EA, Komatsu M, Price-Schiavi SA, Huang D, Guy PM, Carvajal ME, Fregien N, Carraway CA \& Carraway KL 1999 An intramembrane modulator of the ErbB2 receptor tyrosine kinase that potentiates neuregulin signaling. Journal of Biological Chemistry 274 5263-5266. (https://doi.org/10.1074/jbc.274.9.5263)

Carraway CC, Komatsu M, Jepson S, Arango M \& Carraway K 2001 Muc4/ sialomucin complex, a specific intramembrane modulator of ERBB2/ HER2/NEU, potentiates primary tumor growth and suppresses apoptosis in A xenotransplanted melanoma. ScientificWorldJournal 1 149. (https://doi.org/10.1100/tsw.2001.23.248)

Carraway KL, Ramsauer VP, Haq B \& Carothers Carraway CA 2003 Cell signaling through membrane mucins. BioEssays 25 66-71. (https://doi. org/10.1002/bies.10201)

Chaturvedi P, Singh AP, Moniaux N, Senapati S, Chakraborty S, Meza JL \& Batra SK 2007 MUC4 mucin potentiates pancreatic tumor cell proliferation, survival, and invasive properties and interferes with its interaction to extracellular matrix proteins. Molecular Cancer Research 5 309-320. (https://doi.org/10.1158/1541-7786.MCR-06-0353)

Chaturvedi P, Singh AP, Chakraborty S, Chauhan SC, Bafna S, Meza JL, Singh PK, Hollingsworth MA, Mehta PP \& Batra SK 2008 MUC4 mucin interacts with and stabilizes the HER2 oncoprotein in human pancreatic cancer cells. Cancer Research 68 2065-2070. (https://doi. org/10.1158/0008-5472.CAN-07-6041)

Chauhan SC, Singh AP, Ruiz F, Johansson SL, Jain M, Smith LM, Moniaux N \& Batra SK 2006 Aberrant expression of MUC4 in ovarian carcinoma: diagnostic significance alone and in combination with MUC1 and MUC16 (CA125). Modern Pathology 19 1386-1394. (https:// doi.org/10.1038/modpathol.3800646)

Chen AC, Migliaccio I, Rimawi M, Lopez-Tarruella S, Creighton CJ, Massarweh S, Huang C, Wang YC, Batra SK, Gutierrez MC, et al. 2012 Upregulation of mucin 4 in ER-positive/HER2-overexpressing breast cancer xenografts with acquired resistance to endocrine and HER2targeted therapies. Breast Cancer Research and Treatment 134 583-593. (https://doi.org/10.1007/s10549-012-2082-9)

Chen W, Zhang Z, Zhang S, Zhu P, Ko JK \& Yung KK 2021 MUC1: structure, function, and clinic application in epithelial cancers. International Journal of Molecular Sciences 22 6567. (https://doi. org/10.3390/ijms22126567)

Choudhury A, Singh RK, Moniaux N, El-Metwally TH, Aubert JP \& Batra SK 2000 Retinoic acid-dependent transforming growth factorbeta 2-mediated induction of MUC4 mucin expression in human pancreatic tumor cells follows retinoic acid receptor-alpha signaling pathway. Journal of Biological Chemistry 275 33929-33936. (https://doi. org/10.1074/jbc.M005115200)

Coppin L, Vincent A, Frénois F, Duchêne B, Lahdaoui F, Stechly L, Renaud F, Villenet C, Van Seuningen I, Leteurtre E, et al. 2017 Galectin-3 is a non-classic RNA binding protein that stabilizes the mucin MUC4 mRNA in the cytoplasm of cancer cells. Scientific Reports 7 43927. (https://doi.org/10.1038/srep43927)

Duda DG, Duyverman AM, Kohno M, Snuderl M, Steller EJ, Fukumura D \& Jain RK 2010 Malignant cells facilitate lung metastasis by bringing their own soil. PNAS 107 21677-21682. (https://doi.org/10.1073/ pnas.1016234107)

Fidler IJ \& Kripke ML 1977 Metastasis results from preexisting variant cells within a malignant tumor. Science 197 893-895. (https://doi. org/10.1126/science.887927)
Fontebasso Y \& Dubinett SM 2015 Drug development for metastasis prevention. Critical Reviews in Oncogenesis 20 449-473. (https://doi. org/10.1615/CritRevOncog.v20.i5-6.150)

Funes M, Miller JK, Lai C, Carraway 3rd KL \& Sweeney C 2006 The mucin Muc4 potentiates neuregulin signaling by increasing the cell-surface populations of ErbB2 and ErbB3. Journal of Biological Chemistry 281 19310-19319. (https://doi.org/10.1074/jbc.M603225200)

Gabbert H, Wagner R, Moll R \& Gerharz CD 1985 Tumor dedifferentiation: an important step in tumor invasion. Clinical and Experimental Metastasis 3 257-279. (https://doi.org/10.1007/BF01585081)

Ganesh K \& Massagué J 2021 Targeting metastatic cancer. Nature Medicine 27 34-44. (https://doi.org/10.1038/s41591-020-01195-4)

Gao L, Liu J, Zhang B, Zhang H, Wang D, Zhang T, Liu Y \& Wang C 2014 Functional MUC4 suppress epithelial-mesenchymal transition in lung adenocarcinoma metastasis. Tumour Biology 35 1335-1341. (https:// doi.org/10.1007/s13277-013-1178-0)

Gasic GJ, Gasic TB \& Stewart CC 1968 Antimetastatic effects associated with platelet reduction. PNAS 61 46-52. (https://doi.org/10.1073/ pnas.61.1.46)

Gay LJ \& Felding-Habermann B 2011 Contribution of platelets to tumour metastasis. Nature Reviews: Cancer 11 123-134. (https://doi. org/10.1038/nrc3004)

Gkountela S, Castro-Giner F, Szczerba BM, Vetter M, Landin J, Scherrer R, Krol I, Scheidmann MC, Beisel C, Stirnimann CU, et al. 2019 Circulating tumor cell clustering shapes DNA methylation to enable metastasis seeding. Cell 176 98.e14-112.e14. (https://doi.org/10.1016/j. cell.2018.11.046)

Gross MS, Guyonnet-Duperat V, Porchet N, Bernheim A, Aubert JP \& Nguyen VC 1992 Mucin 4 (MUC4) gene: regional assignment (3q29) and RFLP analysis. Annales de Genetique 35 21-26.

Helm RM \& Carraway KL 1981 Evidence for the association of two cell surface glycoproteins of 13762 mammary ascites tumor cells. Concanavalin A-induced redistribution of peanut agglutinin-binding proteins. Experimental Cell Research 135 418-424. (https://doi. org/10.1016/0014-4827(81)90181-6)

Hu Q, Sun W, Qian C, Wang C, Bomba HN \& Gu Z 2015 Anticancer platelet-mimicking nanovehicles. Advanced Materials 27 7043-7050. (https://doi.org/10.1002/adma.201503323)

Huh SJ, Liang S, Sharma A, Dong C \& Robertson GP 2010 Transiently entrapped circulating tumor cells interact with neutrophils to facilitate lung metastasis development. Cancer Research 70 6071-6082. (https://doi.org/10.1158/0008-5472.CAN-09-4442)

Idris N \& Carraway KL 1999 Sialomucin complex (Muc4) expression in the rat female reproductive tract. Biology of Reproduction 61 1431-1438. (https://doi.org/10.1095/biolreprod61.6.1431)

Idris N \& Carraway KL 2000 Regulation of sialomucin complex/Muc4 expression in rat uterine luminal epithelial cells by transforming growth factor-beta: implications for blastocyst implantation. Journal of Cellular Physiology 185 310-316. (https://doi.org/10.1002/10974652(200011)185:2<310::AID-JCP16>3.0.CO;2-W)

Jepson S, Komatsu M, Haq B, Arango ME, Huang D, Carraway CA \& Carraway KL 2002 Muc4/sialomucin complex, the intramembrane ErbB2 ligand, induces specific phosphorylation of ErbB2 and enhances expression of p27(kip), but does not activate mitogen-activated kinase or protein kinaseB/Akt pathways. Oncogene 21 7524-7532. (https://doi. org/10.1038/sj.onc.1205970)

Jonckheere N \& Van Seuningen I 2018 Integrative analysis of the cancer genome atlas and cancer cell lines encyclopedia large-scale genomic databases: MUC4/MUC16/MUC20 signature is associated with poor survival in human carcinomas. Journal of Translational Medicine 16 259. (https://doi.org/10.1186/s12967-018-1632-2)

Jonckheere N, Perrais M, Mariette C, Batra SK, Aubert JP, Pigny P \& Van Seuningen I 2004 A role for human MUC4 mucin gene, the ErbB2 ligand, as a target of TGF-beta in pancreatic carcinogenesis. Oncogene 23 5729-5738. (https://doi.org/10.1038/sj.onc.1207769) (c) 2021 Society for Endocrinology Published by Bioscientifica Ltd. Printed in Great Britain 
Jonckheere N, Vincent A, Perrais M, Ducourouble MP, Male AK, Aubert JP, Pigny P, Carraway KL, Freund JN, Renes IB, et al. 2007 The human mucin MUC4 is transcriptionally regulated by caudal-related homeobox, hepatocyte nuclear factors, forkhead box A, and GATA endodermal transcription factors in epithelial cancer cells. Journal of Biological Chemistry 282 22638-22650. (https://doi.org/10.1074/jbc. M700905200)

Jonckheere N, Skrypek N, Merlin J, Dessein AF, Dumont P, Leteurtre E, Harris A, Desseyn JL, Susini C, Frénois F, et al. 2012 The mucin MUC4 and its membrane partner ErbB2 regulate biological properties of human CAPAN-2 pancreatic cancer cells via different signalling pathways. PLoS ONE 7 e32232. (https://doi.org/10.1371/journal.pone.0032232)

Joshi S, Cruz E, Rachagani S, Guha S, Brand RE, Ponnusamy MP, Kumar S \& Batra SK 2016 Bile acids-mediated overexpression of MUC4 via FAKdependent c-Jun activation in pancreatic cancer. Molecular Oncology 10 1063-1077. (https://doi.org/10.1016/j.molonc.2016.04.007)

Kaur S, Sharma N, Krishn SR, Lakshmanan I, Rachagani S, Baine MJ, Smith LM, Lele SM, Sasson AR, Guha S, et al. 2014 MUC4-mediated regulation of acute phase protein lipocalin 2 through HER2/AKT/ NF- $\mathrm{B}$ signaling in pancreatic cancer. Clinical Cancer Research 20 688-700. (https://doi.org/10.1158/1078-0432.CCR-13-2174)

Komatsu M, Carraway CA, Fregien NL \& Carraway KL 1997 Reversible disruption of cell-matrix and cell-cell interactions by overexpression of sialomucin complex. Journal of Biological Chemistry 272 33245-33254. (https://doi.org/10.1074/jbc.272.52.33245)

Komatsu M, Yee L \& Carraway KL 1999 Overexpression of sialomucin complex, a rat homologue of MUC4, inhibits tumor killing by lymphokine-activated killer cells. Cancer Research 59 2229-2236.

Komatsu M, Jepson S, Arango ME, Carothers Carraway CA \& Carraway KL 2001 Muc4/sialomucin complex, an intramembrane modulator of ErbB2/HER2/Neu, potentiates primary tumor growth and suppresses apoptosis in a xenotransplanted tumor. Oncogene 20 461-470. (https:// doi.org/10.1038/sj.onc.1204106)

Kufe DW 2009 Mucins in cancer: function, prognosis and therapy. Nature Reviews: Cancer 9 874-885. (https://doi.org/10.1038/nrc2761)

Lahdaoui F, Delpu Y, Vincent A, Renaud F, Messager M, Duchêne B, Leteurtre E, Mariette C, Torrisani J, Jonckheere N, et al. 2015 miR-219$1-3 p$ is a negative regulator of the mucin MUC4 expression and is a tumor suppressor in pancreatic cancer. Oncogene 34 780-788. (https:// doi.org/10.1038/onc.2014.11)

Lakshmanan I, Seshacharyulu P, Haridas D, Rachagani S, Gupta S, Joshi S, Guda C, Yan Y, Jain M, Ganti AK, et al. 2015 Novel HER3/MUC4 oncogenic signaling aggravates the tumorigenic phenotypes of pancreatic cancer cells. Oncotarget 6 21085-21099. (https://doi. org/10.18632/oncotarget.3912)

Lambert AW, Pattabiraman DR \& Weinberg RA 2017 Emerging biological principles of metastasis. Cell 168 670-691. (https://doi.org/10.1016/j. cell.2016.11.037)

Li P, Price-Schiavi SA, Rudland PS \& Carraway KL 2001 Sialomucin complex (rat Muc4) transmembrane subunit binds the differentiation marker peanut lectin in the normal rat mammary gland. Journal of Cellular Physiology 186 397-405. (https://doi. org/10.1002/1097-4652(2000)9999:999<000::AIDJCP1037>3.0.CO;2-V)

Li G, Zhao L, Li W, Fan K, Qian W, Hou S, Wang H, Dai J, Wei H \& Guo Y 2014a Feedback activation of STAT3 mediates trastuzumab resistance via upregulation of MUC1 and MUC4 expression. Oncotarget 5 8317-8329. (https://doi.org/10.18632/oncotarget.2135)

Li W, Wu C, Yao Y, Dong B, Wei Z, Lv X, Zhang J \& Xu Y 2014b MUC4 modulates human glioblastoma cell proliferation and invasion by upregulating EGFR expression. Neuroscience Letters 566 82-87. (https:// doi.org/10.1016/j.neulet.2014.02.033)

Li J, Sharkey CC, Wun B, Liesveld JL \& King MR 2016 Genetic engineering of platelets to neutralize circulating tumor cells. Journal of Controlled Release 228 38-47. (https://doi.org/10.1016/j.jconrel.2016.02.036)
Linden SK, Sutton P, Karlsson NG, Korolik V \& Mcguckin MA 2008 Mucins in the mucosal barrier to infection. Mucosal Immunology 1 183-197. (https://doi.org/10.1038/mi.2008.5)

Lomako WM, Lomako J, Soto P, Carraway CA \& Carraway KL 2009 TGFbeta regulation of membrane mucin Muc4 via proteosome degradation. Journal of Cellular Biochemistry 107 797-802. (https://doi. org/10.1002/jcb.22177)

Lou XL, Sun J, Gong SQ, Yu XF, Gong R \& Deng H 2015 Interaction between circulating cancer cells and platelets: clinical implication. Chinese Journal of Cancer Research 27 450-460. (https://doi. org/10.3978/j.issn.1000-9604.2015.04.10)

Matsumura Y, Ito Y, Mezawa Y, Sulidan K, Daigo Y, Hiraga T, Mogushi K, Wali N, Suzuki H, Itoh T, et al. 2019 Stromal fibroblasts induce metastatic tumor cell clusters via epithelial-mesenchymal plasticity. Life Science Alliance 2 e201900425. (https://doi.org/10.26508/ 1sa.201900425)

McNeer RR, Carraway CA, Fregien NL \& Carraway KL 1998 Characterization of the expression and steroid hormone control of sialomucin complex in the rat uterus: implications for uterine receptivity. Journal of Cellular Physiology 176 110-119. (https://doi. org/10.1002/

(SICI) 1097-4652(199807)176:1<110::AID-JCP13>3.0.CO;2-B)

Mejías-Luque R, Peiró S, Vincent A, Van Seuningen I \& De Bolós C 2008 IL-6 induces MUC4 expression through gp130/STAT3 pathway in gastric cancer cell lines. Biochimica et Biophysica Acta 1783 1728-1736. (https://doi.org/10.1016/j.bbamcr.2008.05.020)

Mercogliano MF, De Martino M, Venturutti L, Rivas MA, Proietti CJ, Inurrigarro G, Frahm I, Allemand DH, Deza EG, Ares S, et al. 2017a TNF $\alpha$-induced mucin 4 expression elicits trastuzumab resistance in HER2-positive breast cancer. Clinical Cancer Research 23 636-648. (https://doi.org/10.1158/1078-0432.CCR-16-0970)

Mercogliano MF, Inurrigarro G, De Martino M, Venturutti L, Rivas MA, Cordo-Russo R, Proietti CJ, Fernández EA, Frahm I, Barchuk S, et al. $2017 b$ Invasive micropapillary carcinoma of the breast overexpresses MUC4 and is associated with poor outcome to adjuvant trastuzumab in HER2-positive breast cancer. BMC Cancer 17 895. (https://doi. org/10.1186/s12885-017-3897-x)

Micalizzi DS, Maheswaran S \& Haber DA 2017 A conduit to metastasis: circulating tumor cell biology. Genes and Development 31 1827-1840. (https://doi.org/10.1101/gad.305805.117)

Mimeault M, Johansson SL, Senapati S, Momi N, Chakraborty S \& Batra SK 2010 MUC4 down-regulation reverses chemoresistance of pancreatic cancer stem/progenitor cells and their progenies. Cancer Letters 295 69-84. (https://doi.org/10.1016/j.canlet.2010.02.015)

Moniaux N, Nollet S, Porchet N, Degand P, Laine A \& Aubert JP 1999 Complete sequence of the human mucin MUC4: a putative cell membrane-associated mucin. Biochemical Journal 338 325-333. (https://doi.org/10.1042/bj3380325)

Moniaux N, Chaturvedi P, Varshney GC, Meza JL, Rodriguez-Sierra JF, Aubert JP \& Batra SK 2007 Human MUC4 mucin induces ultrastructural changes and tumorigenicity in pancreatic cancer cells. British Journal of Cancer 97 345-357. (https://doi.org/10.1038/sj. bjc.6603868)

Mukhopadhyay P, Lakshmanan I, Ponnusamy MP, Chakraborty S, Jain M, Pai P, Smith LM, Lele SM \& Batra SK 2013 MUC4 overexpression augments cell migration and metastasis through EGFR family proteins in triple negative breast cancer cells. PLoS ONE 8 e54455. (https://doi. org/10.1371/journal.pone.0054455)

Nagy P, Friedländer E, Tanner M, Kapanen AI, Carraway KL, Isola J \& Jovin TM 2005 Decreased accessibility and lack of activation of ErbB2 in JIMT-1, a Herceptin-resistant, MUC4-expressing breast cancer cell line. Cancer Research 65 473-482.

Nath S \& Mukherjee P 2014 MUC1: a multifaceted oncoprotein with a key role in cancer progression. Trends in Molecular Medicine 20 332-342. (https://doi.org/10.1016/j.molmed.2014.02.007) (c) 2021 Society for Endocrinology Published by Bioscientifica Ltd. Printed in Great Britain 
Nieswandt B, Hafner M, Echtenacher B \& Männel DN 1999 Lysis of tumor cells by natural killer cells in mice is impeded by platelets. Cancer Research 59 1295-1300.

Nollet S, Moniaux N, Maury J, Petitprez D, Degand P, Laine A, Porchet N \& Aubert JP 1998 Human mucin gene MUC4: organization of its 5 '-region and polymorphism of its central tandem repeat array. Biochemical Journal 332 739-748. (https://doi.org/10.1042/ bj3320739)

Pai P, Rachagani S, Dhawan P, Sheinin YM, Macha MA, Qazi AK, Chugh S, Ponnusamy MP, Mallya K, Pothuraju R, et al. 2016 a MUC4 is negatively regulated through the $\mathrm{Wnt} / \beta$-catenin pathway via the Notch effector Hath1 in colorectal cancer. Genes and Cancer 7 154-168. (https://doi. org/10.18632/genesandcancer.108)

Pai P, Rachagani S, Lakshmanan I, Macha MA, Sheinin Y, Smith LM, Ponnusamy MP \& Batra SK $2016 b$ The canonical Wnt pathway regulates the metastasis-promoting mucin MUC4 in pancreatic ductal adenocarcinoma. Molecular Oncology 10 224-239. (https://doi. org/10.1016/j.molonc.2015.10.005)

Palumbo JS, Talmage KE, Massari JV, La Jeunesse CM, Flick MJ, Kombrinck KW, Jirousková M \& Degen JL 2005 Platelets and fibrin(ogen) increase metastatic potential by impeding natural killer cell-mediated elimination of tumor cells. Blood 105 178-185. (https:// doi.org/10.1182/blood-2004-06-2272)

Pantel K \& Speicher MR 2016 The biology of circulating tumor cells. Oncogene 35 1216-1224. (https://doi.org/10.1038/onc.2015.192)

Perez A, Barco R, Fernandez I, Price-Schiavi SA \& Carraway KL 2003 PEA3 transactivates the Muc4/sialomucin complex promoter in mammary epithelial and tumor cells. Journal of Biological Chemistry 278 36942-36952. (https://doi.org/10.1074/jbc.M300264200)

Perez-Vilar J \& Hill RL 1999 The structure and assembly of secreted mucins. Journal of Biological Chemistry 274 31751-31754. (https://doi. org/10.1074/jbc.274.45.31751)

Perrais M, Pigny P, Ducourouble MP, Petitprez D, Porchet N, Aubert JP \& Van Seuningen I 2001 Characterization of human mucin gene MUC4 promoter: importance of growth factors and proinflammatory cytokines for its regulation in pancreatic cancer cells. Journal of Biological Chemistry 276 30923-30933. (https://doi.org/10.1074/jbc. M104204200)

Pino V, Ramsauer VP, Salas P, Carothers Carraway CA \& Carraway KL 2006 Membrane mucin Muc4 induces density-dependent changes in ERK activation in mammary epithelial and tumor cells: role in reversal of contact inhibition. Journal of Biological Chemistry $28129411-29420$. (https://doi.org/10.1074/jbc.M604858200)

Ponnusamy MP, Singh AP, Jain M, Chakraborty S, Moniaux N \& Batra SK 2008 MUC4 activates HER2 signalling and enhances the motility of human ovarian cancer cells. British Journal of Cancer 99 520-526. (https://doi.org/10.1038/sj.bjc.6604517)

Ponnusamy MP, Lakshmanan I, Jain M, Das S, Chakraborty S, Dey P \& Batra SK 2010 MUC4 mucin-induced epithelial to mesenchymal transition: a novel mechanism for metastasis of human ovarian cancer cells. Oncogene 29 5741-5754. (https://doi.org/10.1038/onc.2010.309)

Ponnusamy MP, Seshacharyulu P, Vaz A, Dey P \& Batra SK 2011 MUC4 stabilizes HER2 expression and maintains the cancer stem cell population in ovarian cancer cells. Journal of Ovarian Research 47. (https://doi.org/10.1186/1757-2215-4-7)

Porchet N, Dufosse J, Audie JP, Duperat VG, Perini JM, Nguyen VC, Degand P \& Aubert JP 1991 Structural features of the core proteins of human airway mucins ascertained by cDNA cloning. American Review of Respiratory Disease 144 S15-S18. (https://doi.org/10.1164/ ajrccm/144.3_pt_2.S15)

Price-Schiavi SA, Carraway CA, Fregien N \& Carraway KL 1998 Posttranscriptional regulation of a milk membrane protein, the sialomucin complex (ascites sialoglycoprotein (ASGP)-1/ASGP-2, rat muc4), by transforming growth factor beta. Journal of Biological
Chemistry 273 35228-35237. (https://doi.org/10.1074/ jbc.273.52.35228)

Price-Schiavi SA, Perez A, Barco R \& Carraway KL 2000a Cloning and characterization of the $5^{\prime}$ flanking region of the sialomucin complex/ rat Muc4 gene: promoter activity in cultured cells. Biochemical Journal 349 641-649. (https://doi.org/10.1042/0264-6021:3490641)

Price-Schiavi SA, Zhu X, Aquinin R \& Carraway KL $2000 b$ Sialomucin complex (rat Muc4) is regulated by transforming growth factor beta in mammary gland by a novel post-translational mechanism. Journal of Biological Chemistry 275 17800-17807. (https://doi.org/10.1074/ jbc.275.23.17800)

Price-Schiavi SA, Jepson S, Li P, Arango M, Rudland PS, Yee L \& Carraway KL 2002 Rat Muc4 (sialomucin complex) reduces binding of anti-ErbB2 antibodies to tumor cell surfaces, a potential mechanism for Herceptin resistance. International Journal of Cancer 99 783-791. (https://doi.org/10.1002/ijc.10410)

Rachagani S, Macha MA, Ponnusamy MP, Haridas D, Kaur S, Jain M \& Batra SK 2012 MUC4 potentiates invasion and metastasis of pancreatic cancer cells through stabilization of fibroblast growth factor receptor 1. Carcinogenesis 33 1953-1964. (https://doi.org/10.1093/carcin/ bgs225)

Rakha EA, Boyce RW, Abd El-Rehim D, Kurien T, Green AR, Paish EC, Robertson JF \& Ellis IO 2005 Expression of mucins (MUC1, MUC2, MUC3, MUC4, MUC5AC and MUC6) and their prognostic significance in human breast cancer. Modern Pathology 18 1295-1304. (https://doi.org/10.1038/modpathol.3800445)

Ramsauer VP, Carraway CA, Salas PJ \& Carraway KL 2003 Muc4/ sialomucin complex, the intramembrane ErbB2 ligand, translocates ErbB2 to the apical surface in polarized epithelial cells. Journal of Biological Chemistry 278 30142-30147. (https://doi.org/10.1074/jbc. M303220200)

Ramsauer VP, Pino V, Farooq A, Carothers Carraway CA, Salas PJ \& Carraway KL 2006 Muc4-ErbB2 complex formation and signaling in polarized CACO-2 epithelial cells indicate that Muc4 acts as an unorthodox ligand for ErbB2. Molecular Biology of the Cell 17 2931-2941. (https://doi.org/10.1091/mbc.e05-09-0895)

Reymond N, D’Água BB \& Ridley AJ 2013 Crossing the endothelial barrier during metastasis. Nature Reviews: Cancer 13 858-870. (https://doi. org/10.1038/nrc3628)

Rossi EA, Mcneer RR, Price-Schiavi SA, Van Den Brande JM, Komatsu M, Thompson JF, Carraway CA, Fregien NL \& Carraway KL 1996 Sialomucin complex, a heterodimeric glycoprotein complex. Expression as a soluble, secretable form in lactating mammary gland and colon. Journal of Biological Chemistry 271 33476-33485. (https:// doi.org/10.1074/jbc.271.52.33476)

Rowson-Hodel AR, Wald JH, Hatakeyama J, O'Neal WK, Stonebraker JR, VanderVorst K, Saldana MJ, Borowsky AD, Sweeney C \& Carraway 3rd KL 2018 Membrane mucin Muc4 promotes blood cell association with tumor cells and mediates efficient metastasis in a mouse model of breast cancer. Oncogene 37 197-207. (https://doi.org/10.1038/ onc.2017.327)

Scully OJ, Bay BH, Yip G \& Yu Y 2012 Breast cancer metastasis. Cancer Genomics and Proteomics 9 311-320.

Senapati S, Gnanapragassam VS, Moniaux N, Momi N \& Batra SK 2012 Role of MUC4-NIDO domain in the MUC4-mediated metastasis of pancreatic cancer cells. Oncogene 31 3346-3356. (https://doi. org/10.1038/onc.2011.505)

Sheng ZQ, Hull SR \& Carraway KL 1990 Biosynthesis of the cell surface sialomucin complex of ascites 13762 rat mammary adenocarcinoma cells from a high molecular weight precursor. Journal of Biological Chemistry 265 8505-8510. (https://doi.org/10.1016/S00219258(19)38917-3)

Sheng Z, Wu K, Carraway KL \& Fregien N 1992 Molecular cloning of the transmembrane component of the 13762 mammary adenocarcinoma https://erc.bioscientifica.com https://doi.org/10.1530/ERC-21-0083 (c) 2021 Society for Endocrinology Published by Bioscientifica Ltd. Printed in Great Britain 
sialomucin complex. A new member of the epidermal growth factor superfamily. Journal of Biological Chemistry 267 16341-16346. (https:// doi.org/10.1016/S0021-9258(18)42007-8)

Sherblom AP \& Carraway KL 1980 A complex of two cell surface glycoproteins from ascites mammary adenocarcinoma cells. Journal of Biological Chemistry 255 12051-12059. (https://doi.org/10.1016/S00219258(19)70243-9)

Sherblom AP \& Moody CE 1986 Cell surface sialomucin and resistance to natural cell-mediated cytotoxicity of rat mammary tumor ascites cells. Cancer Research 46 4543-4546.

Sherblom AP, Buck RL \& Carraway KL 1980a Purification of the major sialoglycoproteins of 13762 MAT-B1 and MAT-C1 rat ascites mammary adenocarcinoma cells by density gradient centrifugation in cesium chloride and guanidine hydrochloride. Journal of Biological Chemistry 255 783-790. (https://doi.org/10.1016/S0021-9258(19)86248-8)

Sherblom AP, Huggins JW, Chesnut RW, Buck RL, Ownby CL, Dermer GB \& Carraway KL 1980b Cell surface properties of ascites sublines of the 13762 rat mammary adenocarcinoma. Relationship of the major sialoglycoprotein to xenotransplantability. Experimental Cell Research 126 417-426. (https://doi.org/10.1016/0014-4827(80)90281-5)

Shet T, Valsangar S \& Dhende S 2013 Secretory carcinoma of breast: pattern of MUC 2/MUC 4/MUC 6 expression. Breast Journal 19 222-224. (https://doi.org/10.1111/tbj.12085)

Shibahara H, Tamada S, Goto M, Oda K, Nagino M, Nagasaka T, Batra SK, Hollingsworth MA, Imai K, Nimura Y, et al. 2004a Pathologic features of mucin-producing bile duct tumors: two histopathologic categories as counterparts of pancreatic intraductal papillary-mucinous neoplasms. American Journal of Surgical Pathology 28 327-338. (https:// doi.org/10.1097/00000478-200403000-00005)

Shibahara H, Tamada S, Higashi M, Goto M, Batra SK, Hollingsworth MA, Imai K \& Yonezawa S 2004b MUC4 is a novel prognostic factor of intrahepatic cholangiocarcinoma-mass forming type. Hepatology 39 220-229. (https://doi.org/10.1002/hep.20031)

Singh AP, Moniaux N, Chauhan SC, Meza JL \& Batra SK 2004 Inhibition of MUC4 expression suppresses pancreatic tumor cell growth and metastasis. Cancer Research 64 622-630. (https://doi.org/10.1158/00085472.can-03-2636)

Soto P, Price-Schiavi SA \& Carraway KL 2003 SMAD2 and SMAD7 involvement in the post-translational regulation of Muc4 via the transforming growth factor-beta and interferon-gamma pathways in rat mammary epithelial cells. Journal of Biological Chemistry $\mathbf{2 7 8}$ 20338-20344. (https://doi.org/10.1074/jbc.M301886200)

Soto P, Zhang J \& Carraway KL 2006 Enzymatic cleavage as a processing step in the maturation of Muc4/sialomucin complex. Journal of Cellular Biochemistry 97 1267-1274. (https://doi.org/10.1002/jcb.20718)

Spielman J, Rockley NL \& Carraway KL 1987 Temporal aspects of O-glycosylation and cell surface expression of ascites sialoglycoprotein-1, the major cell surface sialomucin of 13762 mammary ascites tumor cells. Journal of Biological Chemistry 262 269-275. (https://doi.org/10.1016/S0021-9258(19)75922-5)

Srivastava SK, Bhardwaj A, Singh S, Arora S, Wang B, Grizzle WE \& Singh AP 2011 MicroRNA-150 directly targets MUC4 and suppresses growth and malignant behavior of pancreatic cancer cells. Carcinogenesis 32 1832-1839. (https://doi.org/10.1093/carcin/bgr223)

Steeg PS 2016 Targeting metastasis. Nature Reviews: Cancer 16 201-218. (https://doi.org/10.1038/nrc.2016.25)

Talmadge JE \& Fidler IJ 2010 AACR centennial series: the biology of cancer metastasis: historical perspective. Cancer Research 70 5649-5669. (https://doi.org/10.1158/0008-5472.CAN-10-1040)

Tang J, Zhu Y, Xie K, Zhang X, Zhi X, Wang W, Li Z, Zhang Q, Wang L, Wang J, et al. 2016 The role of the AMOP domain in MUC4/Y-promoted tumour angiogenesis and metastasis in pancreatic cancer. Journal of Experimental and Clinical Cancer Research 3591. (https://doi.org/10.1186/s13046-016-0369-0)

Tsuruo T, Kawabata H, Iida H \& Yamori T 1986 Tumor-induced platelet aggregation and growth promoting factors as determinants for successful tumor metastasis. Clinical and Experimental Metastasis 4 25-33. (https://doi.org/10.1007/BF00053470)

Van Klinken BJ, Dekker J, Büller HA \& Einerhand AW 1995 Mucin gene structure and expression: protection vs. adhesion. American Journal of Physiology 269 G613-G627. (https://doi.org/10.1152/ ajpgi.1995.269.5.G613)

VanderVorst K, Dreyer CA, Konopelski SE, Lee H, Ho HH \& Carraway 3rd KL 2019 Wnt/PCP signaling contribution to carcinoma collective cell migration and metastasis. Cancer Research 79 1719-1729. (https://doi. org/10.1158/0008-5472.CAN-18-2757)

Vasseur R, Skrypek N, Duchêne B, Renaud F, Martínez-Maqueda D, Vincent A, Porchet N, Van Seuningen I \& Jonckheere N 2015 The mucin MUC4 is a transcriptional and post-transcriptional target of $\mathrm{K}$-ras oncogene in pancreatic cancer. Implication of MAPK/AP-1, NF-kB and RalB signaling pathways. Biochimica et Biophysica Acta 1849 1375-1384. (https://doi.org/10.1016/j.bbagrm.2015.10.014)

Vincent A, Ducourouble MP \& Van Seuningen I 2008 Epigenetic regulation of the human mucin gene MUC4 in epithelial cancer cell lines involves both DNA methylation and histone modifications mediated by DNA methyltransferases and histone deacetylases. FASEB Journal 22 3035-3045. (https://doi.org/10.1096/fj.07-103390)

Wang C, Mu Z, Chervoneva I, Austin L, Ye Z, Rossi G, Palazzo JP, Sun C, Abu-Khalaf M, Myers RE, et al. 2017 Longitudinally collected CTCs and CTC-clusters and clinical outcomes of metastatic breast cancer. Breast Cancer Research and Treatment 161 83-94. (https://doi. org/10.1007/s10549-016-4026-2)

Weed DT, Gomez-Fernandez C, Bonfante E, Lee TD, Pacheco J, Carvajal ME, Goodwin WJ \& Carraway KL 2001 MUC4 (sialomucin complex) expression in salivary gland tumors and squamous cell carcinoma of the upper aerodigestive tract. Otolaryngology: Head and Neck Surgery 124 127-141. (https://doi.org/10.1067/mhn.2001.112575)

Weigelt B, Peterse JL \& Van't Veer LJ 2005 Breast cancer metastasis: markers and models. Nature Reviews: Cancer 5 591-602. (https://doi. org $/ 10.1038 / \mathrm{nrc1670})$

Workman HC, Miller JK, Ingalla EQ, Kaur RP, Yamamoto DI, Beckett LA, Young LJ, Cardiff RD, Borowsky AD, Carraway KL, et al. 2009a The membrane mucin MUC4 is elevated in breast tumor lymph node metastases relative to matched primary tumors and confers aggressive properties to breast cancer cells. Breast Cancer Research 11 R70. (https://doi.org/10.1186/bcr2364)

Workman HC, Sweeney C \& Carraway 3rd KL 2009b The membrane mucin Muc4 inhibits apoptosis induced by multiple insults via ErbB2dependent and ErbB2-independent mechanisms. Cancer Research 69 2845-2852. (https://doi.org/10.1158/0008-5472.CAN-08-2089)

Wu K, Salas PJ, Yee L, Fregien N \& Carraway KL 1994 Tissue and tumor expression of a cell surface glycoprotein complex containing an integral membrane glycoprotein activator of p185neu. Oncogene 9 3139-3147.

Xu D, Liu S, Zhang L \& Song L 2017 MiR-211 inhibits invasion and epithelial-to-mesenchymal transition (EMT) of cervical cancer cells via targeting MUC4. Biochemical and Biophysical Research Communications 485 556-562. (https://doi.org/10.1016/j.bbrc.2016.12.020)

Yamada N, Nishida Y, Tsutsumida H, Goto M, Higashi M, Nomoto M \& Yonezawa S 2009 Promoter CpG methylation in cancer cells contributes to the regulation of MUC4. British Journal of Cancer 100 344-351. (https://doi.org/10.1038/sj.bjc.6604845)

Zhang J, Perez A, Yasin M, Soto P, Rong M, Theodoropoulos G, Carothers Carraway CA \& Carraway KL 2005 Presence of MUC4 in human milk https://erc.bioscientifica.com

https://doi.org/10.1530/ERC-21-0083 (c) 2021 Society for Endocrinology Published by Bioscientifica Ltd. Printed in Great Britain 
and at the luminal surfaces of blood vessels. Journal of Cellular Physiology 204 166-177. (https://doi.org/10.1002/jcp.20277)

Zhi X, Tao J, Xie K, Zhu Y, Li Z, Tang J, Wang W, Xu H, Zhang J \& Xu Z 2014 MUC4-induced nuclear translocation of $\beta$-catenin: a novel mechanism for growth, metastasis and angiogenesis in pancreatic cancer. Cancer Letters 346 104-113. (https://doi.org/10.1016/j. canlet.2013.12.021
Zhu X, Price-Schiavi SA \& Carraway KL 2000 Extracellular regulated kinase (ERK)-dependent regulation of sialomucin complex/rat Muc4 in mammary epithelial cells. Oncogene 19 4354-4361. (https://doi. org/10.1038/sj.onc.1203781)

Zhu Z, Qiu S, Shao K \& Hou Y 2018 Progress and challenges of sequencing and analyzing circulating tumor cells. Cell Biology and Toxicology 34 405-415. (https://doi.org/10.1007/s10565-017-9418-5)

Received in final form 14 October 2021

Accepted 1 November 2021

Accepted Manuscript published online 2 November 2021 (c) 2021 Society for Endocrinology Published by Bioscientifica Ltd. Printed in Great Britain 